DOI

\title{
ВПЛИВ КОМПЛЕКСНОЇ ТЕРАПІЇ НА ПОКАЗНИКИ ІНДЕКСНОЇ ОЦІНКИ СТАНУ ТКАНИН ПАРОДОНТА
}

\author{
๑Н. І. Сидлярук, І. Р. Мисула
}

\section{ДВНЗ «Тернопільський державний медичний університет імені І. Я. Горбачевського МОз України»}

РЕЗЮМЕ. Актуальною проблемою стоматології на сьогодні $\epsilon$ захворювання слизової оболонки порожнини рота. Проведені дослідження свідчать, що при захворюванняхшлунково-кишкового трактувиникають різноманітні запальні та дистрофічні зміни у СОПР, що $є$ наслідком морфофункціональної та нервово-рефлекторної єдності всього травного каналу.

Метою нашого дослідження було дослідити стан тканин пародонта до та після комплексного лікування з використанням індексів PMA та CPITN в поєднанні з вивченням біохімічних показників сироватки крові.

У всіх груп пацієнтів згідно з індексною оцінкою стану тканин пародонта рівень ЦІК, ЕІ, МДА, ДК був підвищеним, а система АОЗ розбалансована, що свідчило про наявність у хворих ушкоджень тканин. При цьому більш значні зміни показників, а значить і більш значні ушкодження тканин були у хворих з середнім та тяжким ступенями запальних явищ у СОПР та у пацієнтів, які «потребували курсу професійної гігієни», кому «показана місцева протизапальна терапія» і у тих, кому «показане комплексне лікування».

Застосування комплексної терапії дало найкращий позитивний ефект у тих хворих, у яких пародонтальний статус за індексом СРITN відповідав рівню «слід покращити гігієну» та «потребує курсу професійної гігієни». Показники сироватки крові у них фактично не відрізнялися від показників групи пацієнтів, які «лікування не потребують».

КЛЮчОВІ СЛОВА: ушкодження слизової оболонки порожнини рота, гастродуоденіт, пародонтальні індекси, біохімічні показники, сироватка крові.

Вступ. Актуальною проблемою стоматології на сьогодні $\epsilon$ захворювання слизової оболонки порожнини рота (СОПР), що пов'язано із їх знач ною поширеністю, складністю діагностики та лікування [1]. Захворювання СОПР уражають усі вікові категорії населення [2].

Захворювання СОПР $\epsilon$ багатофакторними і часто виникають як супутні при ушкодженнях інших систем організму, найчастіше - шлунковокишкового тракту [3], що $\epsilon$ наслідком морфофункціональної та нервово-рефлекторної єдності всього травного каналу. Тому лише місцева терапія при захворюваннях СОПР не завжди ефективна, що дає поштовх науковцям до пошуку нових підходів та ефективніших препаратів з метою поліпшення результатів лікування.

Метою нашого дослідження було дослідити стан тканин пародонта до та після комплексного лікування у хворих з ушкодженнями СОПР на фоні гастродуоденіту (ГД) за допомогою пародонтальних індексів PMA та CPITN в поєднанні з вивченням біохімічних показників сироватки крові.

Матеріал і методи дослідження. Проспективним дослідженням було охоплено 108 пацієнтів, які мали клінічно встановлений діагноз хронічного гастродуоденіту, репрезентативних за віком та статтю. У пацієнтів були виявлені запально-дистрофічні ушкодження СОПР.

Під час стоматологічного обстеження хворих застосовували такі пародонтальні індекси:
- папілярно-маргінально-альвеолярний індекс (PMA) - для визначення стану пародонтальних тканин (1960);

- індекс CPITN - для визначення пародонтального статусу (1989).

Індексне обстеження пацієнтів проводили до та після комплексного лікування, під час якого частина пацієнтів отримувала загальноприйняту терапію, поєднану із ербісолом. Препарат вводили внутрішньом'язово щоденно двічі на добу, о 6-8 та 20-22 годинах, по 2 мл, протягом 20 діб.

Комплексне дослідження та лікування паці$\epsilon$ нтів, хворих на гастродуоденіт з ушкодженнями СОПР, проведено з використанням клінічних біохімічних, лабораторних методів дослідження. Біохімічними методами досліджували сироватку крові пацієнтів.

Зокрема визначали концентрацію малонового діальдегіду (МДА) за методом [4], активність супероксиддисмутази (СОД) - за методом [5], активність каталази (КАТ) - за методом [6], циркулюючі імунні комплекси (ЦІК) визначали за методом [7], еритроцитарний індекс інтоксикації (EII) за методом [8].

Статистичну обробку результатів здійснювали з використанням t-критерію Стьюдента при p<0,05 у відділі статистичних досліджень ТДМУ імені І. Я. Горбачевського МОЗ України.

Результати й обговорення. Як видно із таблиці 1, рівень ЦІК у групі хворих із середнім сту- 
Огляди літератури, оригінальні дослідження, погляд на проблему

пенем запальних явищ у СОПР був на 7,7 \% вищим, порівняно із показником групи із легким ступенем гінгівіту $(p<0,05)$. Достовірні відмінності були виявлені і у групі хворих з тяжким станом пародонтальних тканин. Активність КТ зменшувалася із погіршанням стану пародонта і була найнижчою у групі пацієнтів із тяжким ступенем запальних явищ у СОПР - на 14,4 \% $(p<0,05)$. Pi- вень МДА досяг найвищих показників у групі пацієнтів із середнім ступенем тяжкості запальних явищ, а рівень ДК виявився найвищим у групі із тяжким ступенем запальних явищ у СОПР - на $21,9 \%(p<0,05)$. При цьому усі описані вище показники достовірно відрізнялися від відповідних показників групи із легким ступенем прояву гінгівіту.

Таблиця 1. Показники ліпідної пероксидації (ЛП), системи антиоксидантного захисту (АОЗ) та ендогенної інтоксикації (ЕІ) у сироватці крові пацієнтів із захворюваннями СОПР на фоні ГД за різного стану пародонтальних тканин за індексом PMA $(\mathrm{M} \pm \mathrm{m})$

\begin{tabular}{|c|c|c|c|}
\hline \multirow[b]{2}{*}{ Показники } & \multicolumn{3}{|c|}{ Стан пародонтальних тканин } \\
\hline & $\begin{array}{c}\text { легкий } \\
(\mathrm{n}=30)\end{array}$ & $\begin{array}{c}\text { середній } \\
(n=70)\end{array}$ & $\begin{array}{c}\text { тажкий } \\
(\mathrm{n}=8)\end{array}$ \\
\hline ЦІК, ум.од. & $215,57 \pm 6,50$ & $233,57 \pm 5,13^{*}$ & $231,13 \pm 3,12 *$ \\
\hline EII, \% & $52,86 \pm 1,46$ & $53,80 \pm 6,34$ & $52,70 \pm 1,41 *$ \\
\hline Кат, \% & $57,20 \pm 1,53$ & $55,44 \pm 0,75$ & $48,98 \pm 1,79 * * *$ \\
\hline МДА, мКмоль/л & $5,81 \pm 0,13$ & $6,11 \pm 0,09 *$ & $5,86 \pm 0,14$ \\
\hline ДК, мКмоль/л & $26,20 \pm 0,19$ & $30,42 \pm 0,15^{*}$ & $33,54 \pm 0,25 * * *$ \\
\hline СОД, од.на 1 мл ер. & $41,60 \pm 0,75$ & $40,78 \pm 0,50$ & $43,01 \pm 1,22 * * *$ \\
\hline
\end{tabular}

Достовірні зміни досліджуваних показників були виявлені у хворих із середнім та тяжким ступенями запальних явищ у СОПР. Очевидно, це зумовлено більш значними запальними ушкодженнями тканин у зазначених груп хворих.

Як видно з таблиці 2, рівень ЦІК був низьким лише у групі пацієнтів, яким потрібно було покращити гігієну РП.

Рівень EII мав тенденцію до підвищення із погіршанням пародонтального статусу РП і найви- щим був у групі пацієнтів, яким була показана місцева протизапальна терапія - на 7,5 \% $(p<0,05)$.

Активність КТ достовірно знижувалася при погіршанні пародонтального статусу і найнижчою виявилася у групі пацієнтів, яким було показане комплексне лікування - на 18,6 \% ( $<<0,05)$. Рівень МДА та ДК поступово підвищувався і досяг свого максимуму у групах хворих із найгіршим пародонтальним статусом. Активність СОД виявилася найнижчою у групі хворих, яким була показана місцева протизапальна терапія.

Таблиця 2. Показники ЛП, системи АОЗ та ЕІ у сироватці крові пацієнтів із захворюваннями СОПР на фоні ГД

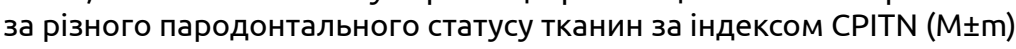

\begin{tabular}{|c|c|c|c|c|c|}
\hline \multirow[b]{2}{*}{ Показники } & \multicolumn{5}{|c|}{ Пародонтальний статус } \\
\hline & $\begin{array}{c}0-(\text { лікування } \\
\text { не потребує) } \\
(n=11)\end{array}$ & $\begin{array}{c}1 \text { - (слід покращити } \\
\text { гігієну) } \\
(\mathrm{n}=21)\end{array}$ & $\begin{array}{c}2 \text { - (потребує } \\
\text { курс проф. } \\
\text { гігієни) } \\
(\mathrm{n}=41)\end{array}$ & $\begin{array}{c}3 \text { - (показана місцева } \\
\text { протизапальна } \\
\text { терапія) } \\
(\mathrm{n}=29)\end{array}$ & $\begin{array}{c}\text { 4- (показане } \\
\text { комплексне } \\
\text { лікування) } \\
(n=6)\end{array}$ \\
\hline ЦІК, ум.од. & $229,55 \pm 12,67$ & $207,48 \pm 6,13^{*}$ & $234,83 \pm 6,61$ & $230,03 \pm 8,10$ & $247,50 \pm 17,18$ \\
\hline EII, \% & $51,36 \pm 1,95$ & $53,59 \pm 1,84$ & $52,42 \pm 0,86$ & $55,52 \pm 1,31 *$ & $53,97 \pm 1,73$ \\
\hline Кат, \%++ & $59,26 \pm 1,95$ & $55,36 \pm 1,69 *$ & $55,53 \pm 1,00 *$ & $55,44 \pm 1,19 *$ & $48,25 \pm 1,45$ \\
\hline МДА, мкмоль/л & $5,73 \pm 0,19$ & $5,85 \pm 0,17$ & $6,06 \pm 0,12^{*}$ & $6,19 \pm 0,13^{*}$ & $5,91 \pm 0,17$ \\
\hline ДК, мКмоль/л & $25,47 \pm 0,33$ & $26,82 \pm 0,23^{*}$ & $29,67 \pm 0,12^{*}$ & $31,80 \pm 0,15^{*}$ & $33,60 \pm 0,34^{*}$ \\
\hline СОД, од.на 1 мл ер. & $42,16 \pm 1,25$ & $41,36 \pm 1,00$ & $41,34 \pm 0,55$ & $39,43 \pm 0,70 *$ & $46,00 \pm 1,71$ \\
\hline
\end{tabular}


Огляди літератури, оригінальні дослідження, погляд на проблему

Результати проведених досліджень свідчать, що із погіршенням пародонтального статусу пацієнтів в сироватці крові збільшуються показники рівнів EII, МДА, ДК, знижуєТься, а деколи підвищується активність системи АОЗ, що, на нашу думку, свідчить про наростання ушкоджень тканин.

Узагальнюючи результати вивчення показників рівнів EІ, ЛП, активності системи АОЗ у сироватці крові хворих до лікування в залежності від стану пародонта за індексами РМА та СРITN слід зазначити, що у всіх груп пацієнтів рівні ЦІК, Еl, МДА, ДК були підвищеними, а система АОЗ - розбалансованою, що свідчить про наявність у хворих ушкоджень тканин, при цьому більш значні зміни показників, а значить і більш значні ушкодження

тканин мали місце у хворих із середнім та тяжким ступенями запальних явищ у СОПР та у пацієнтів, які потребували курсу професійної гігієни, яким була показана місцева протизапальна терапія і у тих, кому було показано комплексне лікування.

У таблицях 3 і 4 наведені результати досліджень після проведеного патогенетично обгрунтованого комплексного лікування.

Дані таблиці 3 свідчать, що рівні ЦІК та МДА у всіх групах хворих достовірно не змінилися. Натомість рівні Ell, ДК, активність КТ та СОД в сироватці крові із погіршанням стану пародонтальних тканин зростали і загалом виявилися найвищими у групі пацієнтів з тяжким станом пародонтальних тканин.

Таблиця 3. Показники ЛП, ЕІ та системи АОЗ у сироватці крові хворих залежно від стану пародонтальних тканин

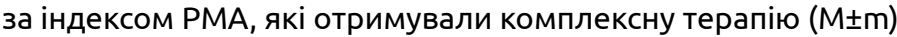

\begin{tabular}{|c|c|c|c|c|}
\hline \multirow[b]{2}{*}{ Показники } & \multicolumn{4}{|c|}{ Стан пародонтальних тканин } \\
\hline & $\begin{array}{l}\text { норма } \\
(\mathrm{n}=17)\end{array}$ & $\begin{array}{c}\text { легкий } \\
(n=56)\end{array}$ & $\begin{array}{c}\text { середній } \\
(n=9)\end{array}$ & $\begin{array}{c}\text { тяжкий } \\
(\mathrm{n}=6)\end{array}$ \\
\hline $\begin{array}{c}\text { ЦІК, } \\
\text { ум. од. }\end{array}$ & $85,35 \pm 2,28$ & $82,21 \pm 1,81$ & $83,89 \pm 4,11$ & $79,33 \pm 4,78$ \\
\hline $\begin{array}{c}\text { Ell, } \\
\%\end{array}$ & $26,23 \pm 0,35$ & $27,67 \pm 0,38$ * & $29,34 \pm 0,71 * * *$ & $27,07 \pm 0,70 * * *$ \\
\hline $\begin{array}{c}\text { Каталаза, } \\
\%\end{array}$ & $18,46 \pm 0,51$ & $19,13 \pm 0,22$ & $19,59 \pm 0,62$ & $20,40 \pm 0,51 * * *$ \\
\hline $\begin{array}{c}\text { МДА, } \\
\text { мКмоль/л }\end{array}$ & $2,36 \pm 0,15$ & $2,62 \pm 0,14$ & $2,23 \pm 0,14$ & $2,26 \pm 0,22$ \\
\hline $\begin{array}{c}\text { ДК, } \\
\text { мКмоль/л }\end{array}$ & $19,97 \pm 0,49$ & $21,23 \pm 0,30 *$ & $20,86 \pm 0,40$ ** & $22,95 \pm 0,42 * * * * * *$ \\
\hline $\begin{array}{c}\text { СОД, } \\
\text { од. на } 1 \text { мл еритр. }\end{array}$ & $61,42 \pm 1,04$ & $62,31 \pm 0,72$ & $64,69 \pm 1,50 * * *$ & $64,82 \pm 2,19$ \\
\hline \multicolumn{5}{|c|}{$\begin{array}{l}\text { * - достовірність відмінності показника відносно показника групи «Норма», p<0,05; } \\
\text { ** - достовірність відмінності показника відносно показника групи «Легкий», p<0,05; } \\
\text { *** - достовірність відмінності показника відносно показника групи «Середній», p<0,05. }\end{array}$} \\
\hline
\end{tabular}

Комплексне лікування виявило найкращий лікувальний ефект у хворих з легким ступенем запальних явищ пародонтальних тканин, відносно добрий - з середнім і задовільний - з високим.

Дані, наведені у таблиці 4, свідчать, що достовірні відмінності з групою хворих, які не потребували лікування, були виявлені у пацієнтів, яким була показана місцева протизапальна терапія. Зміни досліджуваних показників у цієї групи хворих мали різноспрямований характер. Зокрема, рівні ЦІК та ДК у плазмі крові були достовірно меншими, рівень МДА та активність каталази більшими, а рівень Ell та активність СОД практично не відрізнялися від показника групи порівняння.

Отже, застосування комплексної терапії дало найкращий позитивний ефект у хворих, в яких пародонтальний статус відповідав рівню «слід покращити гігієну» та «потребує курсу професійної гігієни». Показники сироватки крові у них фактич- но не відрізнялися від показників групи пацієнтів, які «лікування не потребували».

У групі хворих, яким за пародонтальним статусом була «показана місцева протизапальна терапія» показники хоча й мали різноспрямовані зміни, але загалом свідчили про позитивний ефект комплексної терапії, зокрема, показники рівнів ЦІК, ДК у них були нижчими, а рівень EII, активність КТ та СОД перебували на рівні показників групи порівняння.

Найкращий лікувальний ефект комплексної терапії спостерігали у хворих з легким ступенем запальних явищ пародонтальних тканин, відносно добрий - з середнім і задовільний - з тяжким. Позитивний ефект комплексної терапії був виявлений також у тих хворих, у яких породонтальний статус відповідав рівню «слід покращити гігієну», «потребує курсу професійної гігієни», і навіть у тих, кому «показана місцева протизапальна терапія». 
Огляди літератури, оригінальні дослідження, погляд на проблему

Таблиця 4. Показники ЛП, системи АОЗ та ЕІ у сироватці крові хворих в залежності від пародонтального статусу за індексом CPITN, які отримували комплексну терапію $(\mathrm{M} \pm \mathrm{m})$

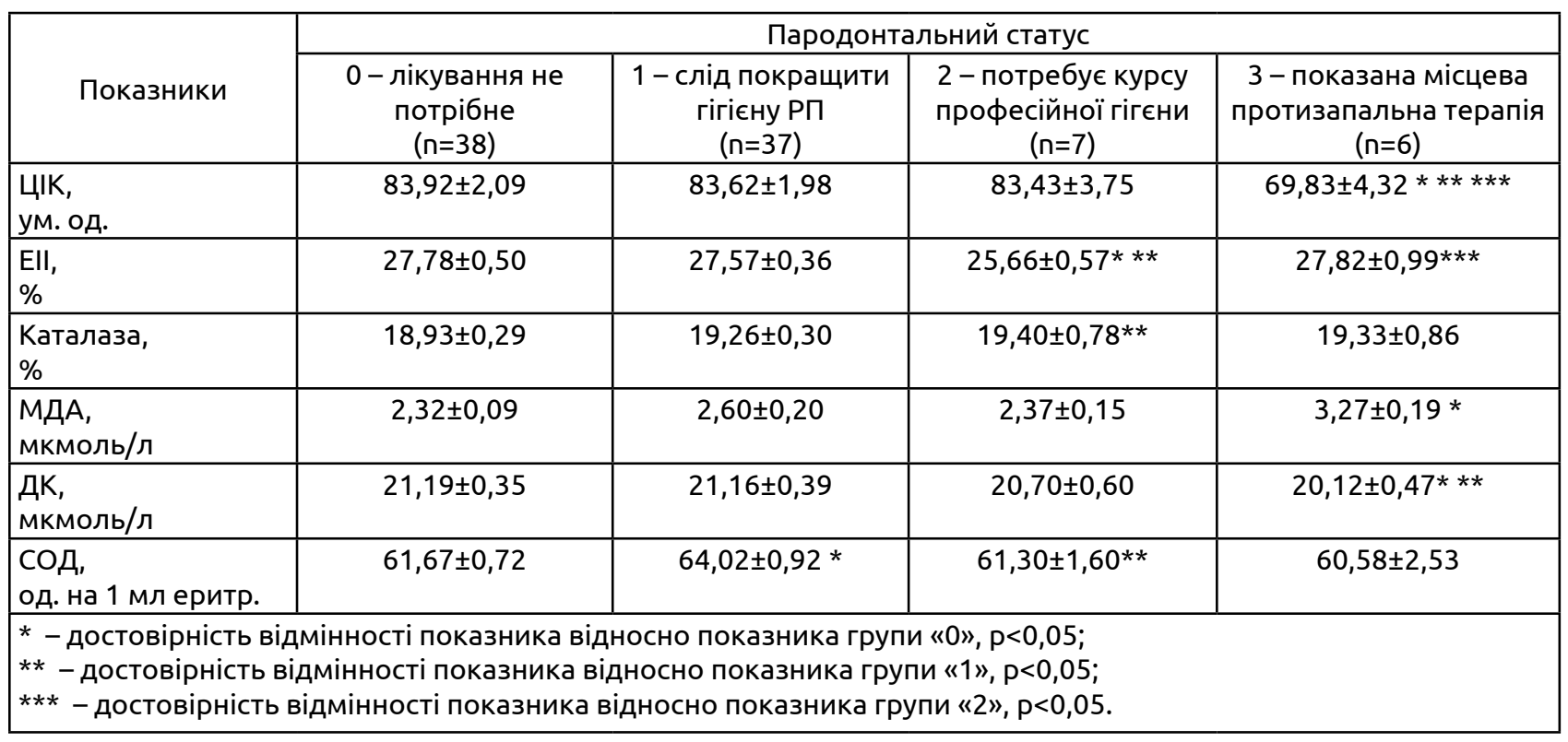

Висновки. 1.У хворих з ушкодженнями СОПР, викликаними ГД, більш значні зміни показників рівнів ЦІК, ЕІ, МДА, ДК, активності каталази та СОД, наростання дисбалансу системи АОЗ в сироватці крові, а значить і більш значні ушкодження тканин мали місце у хворих з середнім та тяжким ступенями запальних явищ у СОПР та у пацієнтів, які потребували курсу професійної гігієни, яким була показана місцева протизапальна терапія і у тих, кому було показане комплексне лікування.

2. Після комплексного лікування показники ендогенної інтоксикації, рівня ЛП та активності системи АОЗ у сироватці крові хворих достовірно покращилися, був повністю усунутий дисбаланс системи АОЗ.

\section{ЛITEPATУРA}

1. Tooth loss and periodontitis by socio-economic status and inflammation in longitudinal population-based study / S. Buchwald, T. Kocher, R. Biffar [et al.] // Journal of Clinical Periodontology. - 2013. - Vol. 40, № 3. P. 203-211.

2. Заболотний Т. Д. Стан тканин пародонта при ревматизмі / Т. Д. Заболотний, О. О. Мигаль // Практична медицина. - 2013. - Т. 19, Вип. 1. - С. 192-199.

3. Рябоконь Е. Н. Особенности лечения генерализованного пародонтита, сочетанного с язвенной болезнью желудка и дванадцатиперстной кишки / Е. Н. Рябоконь, И. И. Соколова, В. В. Олейничук // Український стоматологічний альманах. - 2013. - № 6. - С. 38-43.

4. Владимиров Ю. А. Перекисное окисление липидов в биологических мембранах / Ю. А. Владимиров, А. И. Арчаков. - М. : Медицина, 1972. - 252 с.
3. Застосування комплексної терапії дало найкращий позитивний ефект у тих хворих, у яких пародонтальний статус за індексом CPITN відповідав рівню «слід покращити гігієну» та «потребує курсу професійної гігієни». Показники сироватки крові у них фактично не відрізнялися від показників групи пацієнтів, які «лікування не потребують».

Перспективи подальших досліджень. Результати дослідження спонукають до подальшого вивчення впливу комплексної терапії на показники слини та сироватки крові пацієнтів різних груп для підбору індивідуальної дози препарату.

5. Чевари С. Роль супероксиддисмутазы в окислительных процессах и метод определения ее в биологическом материале / С. Чевари, И. Чаба, Й. Секей // Лаб. дело. - 1985. - № 11. - С. 678-681.

6. Королюк М. А. Метод определения активности каталазы / М. А. Королюк, Л. И. Иванова, И. Г. Майорова, В. Е. Токарев // Лабораторное дело. - 1988. - № 1. C. 16-18.

7. Гриневич Ю. А. Определение иммунных комплексов в крови онкологических больных / Ю. А. Гриневич, А. М. Алферов // Лабораторное дело. - 1981. № 8. - С. 493-495.

8. Способ диагностики эндогенной интоксикации / А. А. Тогайбаев, А. В. Кургузкин, И. В. Рикун, Р. М. Карибжанова // Лабораторное дело. - 1988. - № 9. - С. 22-24. 


\section{Horbachevsky Ternopil State Medical University}

SUMMARY. Diseases of oral mucous membrane are one of the the most actual dental problems nowadays. The conducted researches prove that gastrointestinal tract diseases influence on various inflammatory and degenerative changes in the oral mucosa, that are the result of morphofunctional unity of the entire gastrointestinal tract.

The aim of our study was to investigate the state of parodontal tissues before and after combined treatment using parodontal PMA and CPITN indexes combined with the study of biochemical parameters of blood serum.

According to the parodontal indexes assessment in all groups of patients the level of CIC, EI, MDA, DC increased, and the system of antioxydant defence was disbalanced, what explains the result - tissue damage. More significant changes and tissue damage occurred in group of patients with medium or severe inflammation in the oral mucosa according to PMA index; patients who "needed the professional cleaning", patients who "needed local anti-inflammatory therapy" and those who "needed combined treatment" according to CPITN index.

The use of combined therapy leaded to the best positive effect in those patients who "should improve oral hygiene" and "require professional care" according to periodontal status. Numbers did not significantly differ from patients who "do not require treatment."

KEY WORDS: oral mucous membrane, gastroduodenitis, parodontal indexes. 